\title{
Contraception and reproductive planning from the perspective of women with sickle cell disease
}

\author{
Contracepção e planejamento reprodutivo na percepção \\ de mulheres com doença falciforme \\ Anticoncepción y planificación reproductiva en la \\ percepción de mujeres con anemia falciforme
}

How to cite this article: Pedrosa EN, Corrêa MSM, Ferreira ALCG, Sousa CES, Silva RA, Souza Al. Contraception and reproductive planning from the perspective of women with sickle cell disease. Rev Gaúcha Enferm. 2021;42:e20200109. doi: https://doi. org/10.1590/1983-1447.2021.20200109 a Instituto de Medicina Integral Prof. Fernando Figueira (IMIP), Programa de Pós Graduação Doutorado em Saúde Integral. Recife, Pernambuco, Brasil.

- Faculdade Pernambucana de Saúde (FPS), Curso de Medicina. Recife, Pernambuco, Brasil.

Universidade de Pernambuco (UPE), Faculdade de Enfermagem Nossa Senhora das Graças. Recife, Pernambuco, Brasil.

${ }^{d}$ Instituto de Medicina Integral Prof. Fernando Figueira (IMIP), Centro de Atenção à Mulher, Ambulatório de Ginecologia. Recife, Pernambuco, Brasil.

- Secretaria Municipal de Saúde de Santa Cruz do Capibaribe, Departamento de Vigilância Epidemiológica. Santa Cruz do Capibaribe, Pernambuco, Brasil.

¡ Real Hospital Português de Beneficência. Recife, Pernambuco, Brasil.

\section{ABSTRACT}

Objective: To understand the perceptions of women with sickle cell disease $(S C D)$ about reproductive planning in a public health service.

Method: This is a qualitative study conducted with 15 women with SCD attended at a public hospital in Recife, between August 2018 and May 2019. Bardin's content analysis technique was used.

Results: The women were between 25 and 38 years old, married, and had low education. After the analysis, four thematic categories emerged: information about contraception, use of contraceptive methods, feelings about pregnancy, and gynecological consultation. It was found that women with SCD are influenced by factors such as fear of complications during pregnancy, lack of information on reproductive planning, partners and health professional opinion, and difficulties in health service access.

Final considerations: The reports demonstrate that health workers need to improve the way through which information reaches the patient, to offer a more satisfactory professional practice.

Keyword: Women. Anemia, sickle cell. Contraception. Qualitative research.

\section{RESUMO}

Objetivo: Compreender as percepções de mulheres com doença falciforme (DF) sobre planejamento reprodutivo em serviço público de saúde.

Método: Estudo qualitativo onde foram entrevistadas 15 mulheres com DF atendidas em um hospital público em Recife, entre agosto/2018 e maio/2019. Foi empregada a técnica de análise de conteúdo temática de Bardin.

Resultados: As mulheres tinham entre 25 e 38 anos, eram casadas e de baixa escolaridade. Após a análise emergiram quatro categorias temáticas: informações sobre contracepção, uso de contraceptivos, sentimento sobre gestação e consulta ginecológica. Observou-se que a mulher com DF sofre influência de fatores como medo da gestação, falta de informação sobre planejamento reprodutivo, influência do parceiro e do profissional de saúde e dificuldades de acesso ao serviço de saúde.

Considerações finais: Os relatos demonstram que os profissionais de saúde precisam melhorar a forma como à informação chega à paciente de modo a oferecer uma prática profissional mais satisfatória.

Palavras-chave: Mulheres. Anemia falciforme. Anticoncepção. Pesquisa qualitativa.

\section{RESUMEN}

Objetivo: Comprender las percepciones de las mujeres con anemia de células falciformes (AF) sobre la planificación reproductiva en un servicio de salud pública.

Método: Estudio cualitativo donde se atendió a 15 mujeres con AF en un hospital público de Recife, entre agosto de 2018 y mayo de 2019. Se utilizó la técnica de análisis de contenido temático de Bardin.

Resultados: Las mujeres tenían entre 25 y 38 años, estaban casadas y tenían baja escolaridad. El análisis generó cuatro categorías temáticas: información sobre anticoncepción, uso de anticonceptivos, sentimientos sobre el embarazo y consulta ginecológica. Se observó que las mujeres con AF son influenciadas por factores como el miedo del embarazo, la falta de información sobre planificación reproductiva, la influencia de su pareja y del profesional de la salud, y dificultades para acceder al servicio de salud.

Consideraciones finales: Los informes demuestran que los profesionales de la salud necesitan mejorar la forma en que la información llega al paciente para ofrecer una práctica profesional más satisfactoria.

Palabras clave: Mujeres. Anemia de células falciformes. Anticoncepción. Investigación cualitativa. 


\section{口INTRODUCTION}

Sickle cell disease (SCD) is the term used to characterize a group of blood disorders with structural changes in the chain of hemoglobin $(\mathrm{Hb})$ production, which generate a variant called HbS(1). It has many distinct forms, among which the homozygous one (HbSS) called sickle cell anemia, the most known and severe.

Since it affects a high number of people from African descent, the disease is considered to be an ethnic or racial disease, and has high morbidity and mortality rates ${ }^{(1)}$. With the introduction of different strategies that allowed for an increase in the survival of people with SCD, for instance, the use of hydroxyurea to prevent sickle cell crises, the survival rates of people with SCD increased ${ }^{(2)}$. As a result, a higher number of women with SCD has been reaching reproductive age without the adequate reproductive planning, leading to unplanned gestations and to a higher risk of pregnancy, puerperal, and clinical complications ${ }^{(3)}$. On the other hand, health professionals from the primary health care network are not secure in their attention to this group of women, which has had a negative impact in the creation of a worker/patient bond, leading these women to stop seeking health services, and contributing to increase the severity of the $\mathrm{SCD}^{(4)}$.

Reproductive planning is a right of the users of the Single Health System (SUS). It is an integral part of the set of actions of women or couple care, being considered part of the integral attention to health by Law 9.263/1996(5).

The choice of the contraceptive method must consider the medical eligibility criteria established by the World Health Organization (WHO), based on the clinical situation, on advantages and possible adverse effects of the methods, in addition to the desires of each woman ${ }^{(6)}$. The level of knowledge, the financial resources, the stigma with regard to contraceptive methods/techniques, the building of a bond between worker and users, are all among the reasons for which women with SCD have difficulties accessing the health services and having adequate reproductive planning ${ }^{(4,7)}$.

Considering SCD as a chronic disease, which can lead women affected by it to construct meanings regarding their way of living, their health care, and reverberate on their access and use of contraceptive methods, this study attempted to understand these women based on the works of Gadamer, an author who reflects about human beings in issues related to health and to the role of the health worker in the process of achieving a cure ${ }^{(8)}$. Therefore, the guiding question of this study is to understand the perceptions of women with SCD about the assistance they received with regard to contraception and reproductive planning in a public health service.

\section{METHOD}

This is a qualitative study developed in the specialized outpatient clinic of a public hospital in Recife, in the Brazilian Northeast, from August 2018 to May 2019. This outpatient clinic was created in 2017 to provide gynecological and obstetric assistance to women with SCD. The sample was made up by 15 women and determined by theoretical saturation, that is, sampling was considered done when the inclusion of new participants stopped adding new information for analysis ${ }^{(9)}$. Data collection was carried out through a semistructured interview, lasting for a mean of 45 minutes, recorded and transcribed in full, preserving the originality of statements and having these guiding questions: how did you use the method to prevent pregnancies before receiving attention at this service? What were your perceptions about the attention in the gynecological consultation of this service? What were your perceptions about the role of the health worker of this service in your choice for a method to prevent pregnancy?

The participants of the research were women who attended to the inclusion criteria: diagnosed with $S C D$, being on gynecological follow up in the service, being older than 18 years old, having an active sex life, and wishing to prevent pregnancy. To analyze the data, a content analysis was used, as recommended by Bardin, in order to understand what is hidden in the lines of the women about reproductive planning in a public health service ${ }^{(10)}$. The analysis followed the three stages of the thematic modality. The pre-analysis, in which the material collected was organized and the hypotheses were elaborated after it was skimmed, allowing for the composition of the corpus of the research based on the following rules: exhaustiveness, representativity, homogeneity, pertinence, and exclusivity. In the second stage, the exploration of the material, the statements were categorized, so the different and similar information could be grouped and coded between the different discourses and practices. In the treatment of the results, the third and last stage, the content and the meaning of the lines were inferred, to compare and unify the reports of the interviewees. The discourses of the women were identified using the letter "P", followed by a number attributed to them according to the order in which the interview was carried out. Four different researchers carried out the analysis, to broaden the understanding of the interrelations between the subjective and contextual dimensions.

Based on this process, four thematic categories emerged: information on contraceptive methods; use of contraceptive methods; feeling with regard to gestation; and gynecological consultations. 
This study was in accordance to Resolution 510/16, from the National Council of Health of the Brazilian Ministry of Health. It was approved by the Research Ethics Committee (CAAE: 04201718.8.0000.5201) and all participants signed the Free and Informed Consent Form.

\section{RESULTS AND DISCUSSION}

The women from this study were from 25 to 38 years old and were, mostly, married, originating from the metropolitan region of the city of Recife, with a family income varying from one to two minimum wages. Regarding their educational level, half the sample had not concluded high school, and only two had finished higher education. The women were not in the job market, and their only source of income was welfare for the ill.

The impossibility of studying due to frequent sickle cell crises, recurring hospitalizations, and the fear of going to school, represent an issue of vulnerability, which affected the social and intellectual context of a childhood which took place between the hospital and the house. The constant crises and the complications of the disease, in addition to affecting the physical and psychological condition of women with SCD, often interfere in the roles of student and worker ${ }^{(7)}$. This corroborates the discourses found in this study, according to which women often face obstacles that prevent them from studying or firming their position at a job, which often makes them dependent on welfare for the ill.

All participants of the research had been diagnosed, still in their childhood, with the HbSS genotype of the disease, that is, its homozygous form, which is the most severe. Only one participant was diagnosed only at 25 years old, during her first pregnancy. Regarding their race/color, 14 women consider themselves to be black, with the exception of one participant, who self-declared being white. Since this is a hematologic hereditary disease of African ascent, the issue of race/color is an important factor. This is especially true in Brazil, an ethnically mixed country, where a great portion of the population declares to be brown/black ${ }^{(11)}$.

\section{Information about contraceptive methods}

There was a relation between the care with health and the importance of having information about the use of contraceptive methods in the prevention of unplanned pregnancies. The desire for information and to overcome stigmas about the disease reflects the need to disseminate knowledge, as the following statements show:
[...] / wanted to get everyone with sickle cell together and give a lot of lecture and call many professionals, to talk about contraceptives, medications, and instruct people, because it is very important to know aboutyour disease [...] because there is a lot of lack of information, I always said there that I always wanted to create something before I die, to create something to help people with sickle cell to change (the situation), you understand? Something that could help and show them this is not the end. (P5)

[...] there's a lot of people, they don't understand, don'teven know [...] you don't need to have an unwanted pregnan$c y$, because they don't know the methods that you can, right [...] So, like, the person has to know, to explore all of them, right, because ifyou can't get adapted to one, you have to know the other so you can use them, right. (P12)

In many statements, it was possible to note that the woman with SCD did not know what reproductive planning is. From the 15 participants, 11 said that they had never heard the term "family planning"in the consultations in the primary health care units and in the specialize centers where they go to their follow ups. However, it was reported that they had the opportunity to get to know the contraceptive methods as they started to receive attention at the institution.

\section{[...] family planning? Is this a question, or there's already [...] Is it like, the beginning of pregnancy? (P8) \\ [...] no, and the doctors / went to to get examined didn't tell menever about it (contraceptive), I took it myself and when I wanted to change it I changed it. (P6)}

The lack of information about contraceptive methods is related to the need for a space for the dialog between the health professional and the patient, since, to Gadamer, dialog is a part of treatment ${ }^{(8)}$. From this perspective, this moment must be free of pre-conceptions, so the professional can evaluate the need for health, which, in this study, involves questions of contraception and reproductive planning.

The Ministry of Health (MS)(11) prescribes that all women must be informed about all contraceptive methods and about the risks of pregnancy, but each woman must be evaluated with regard to individual risks. Each woman must choose the method that is most appropriate to their reality, allowing for a safe sexual practice which is not only associated to the reproductive function ${ }^{(12)}$.

The reality experienced by the women in this study is that they did not receive, during most of their lives, information 
about contraception, as opposed to what the MS recommends. The reports presented demonstrate the lack of access to safe information for the adequate use of contraceptives, favoring self-medication or perpetuating doubts, fears, and anxieties.

\section{[...] / started to take ciclo 21 [a contraceptive] by myself \\ [...] it was from my head. I heard about it, my sister took it, I saw her taking it and I decided to take it too [...] then, one month, two months later I had a consultation with my doctor [...] then I told her, and she said: no, there's no problem, the problem is when you don't take it. (P01) \\ [...] / didn't even knew these things gave you thrombosis. llearned that here. (P6)}

Guidance about reproductive planning should be present in all health services. From this perspective, the importance of nurses as part of the health team in the process of caring for women who seek attention stands out, as they provide clear and objective information to strengthen the bond between worker and patient ${ }^{(13)}$.

\section{Use of contraceptive methods}

A correct use of the method is related to the access to information about its right use, its benefits, side effects, and possible complications of continuous use ${ }^{(12)}$. A study carried out in Paraná(14) found that one third of women who use hormonal contraception started to use it with no previous medical guidance, and nearly half participants had some contraindication to its use, according to the eligibility criteria established by the $\mathrm{WHO}^{(6)}$. This corroborates the findings of this study, according to which part of the participants reported having started to use contraceptive methods without the guidance from a health professional and having presented side effects in their first experiences with contraceptive methods.

[...] pelutan [contraceptive injection] was coming with clots [menstruation] and then I went to the gynecologist again, she prescribed level [oral contraceptive] but a month, two went by, and on the third it started again, the pieces, it was that problem down there, I menstruated, it didn't go, I bled 22 days straight, then my husband was carrying me on his arms [...] I felt pain, colics. (P10)

[...] The pill made me more icteric, I felt that the veins, I don't know, they jump, be harder. Only when I took it... after I took depoprovera [contraceptive], the injection, 3 months later, I got an embolism. (P14)
Starting with the emergence of secondary sexual characteristics, women must receive information about their reproductive systems and contraception ${ }^{(15)}$. This became evident in the statements of the participants, when they reported the health problems they attributed to the use of the contraceptive. This makes it clear how their knowledge about the correct use of the contraceptive methods is lacking. This can be related to lack of guidance which can lead to self-medication.

The use of contraceptive methods with no adequate guidance favors the non-adherence and the discontinued use, contributing for the occurrence of adverse effects and to unplanned pregnancies. Contraception in women with SCD must be safely managed by health workers, who must guide them with regard to the contraceptive methods that are better adapted to the clinical conditions of women, allowing them to have the autonomy to choose, the power to decide, considering a safe and effective use ${ }^{(16)}$.

For the guidance about contraceptive methods to be successful, the health worker must act carefully with regard to the health situation of the patient. That would lead the health professional and the patient to be imbued with the same desire to establish balance in health. This is possible through dialog, which, according to Gadamer, can abolish distancing in the relation between health professional and patient ${ }^{(8)}$

When women were questioned about the current use of contraceptives, they did not report any difficulties to purchase the contraceptives, since the ambulatory of the service made them available free of charge. The medroxyprogesterone acetate (injected each trimester) was found to be the most accepted method, followed by condom for men.

According to the eligibility criteria from the $\mathrm{WHO}^{(6)}$, the use of medroxyprogesterone by women with SCD is classified as being of category I. For some authors, the medroxyprogesterone is found to be the first choice method among women with $S C D$, since it is practical, tolerable, and diminishes the risk of vein thrombosis and pain crises ${ }^{(15-16)}$.

During the interviews, there were no reports of persistent side effects with the use of medroxyprogesterone. However, it was possible to find that some women were dissatisfied with some of its side effects, such as the lack of menstruation, which, sometimes, led to the feeling of a false pregnancy. The following lines show this dissatisfaction:

[...] well, it doesn't come, the period doesn't come, right? And you're like: o my God! I look at myself in the mirror a lot. Then I get paranoid, every day l look myself in the mirror and tell myself my body is normal, I know 
it changes, I've been pregnant before so I know some things change. (P5)

[...] I preferred to change because I was feeling a lot of pain in the first month I took the injection [...] it's from the hip below, the legs hurt a lot, this region here (points at the region), and sometimes I'm bedridden really. (P13)

Regarding the use of the condom, a method which provides double protection, since in addition to be contraceptive it prevents sexually transmitted infections $(\mathrm{STIS})^{(15)}$, the statements of the women show the lack of satisfaction and trust in the safety of this method:

[...] it's better without the condom, but I like to prevent. At first I was allergic right, so I always had an itch in the vagina afterwards, but now I think the organism accepted it, you know, so it stop [...] to stop using... well, only if a person decides to get pregnant. (P8)

[...] l, right now, I'm using it [condom] because I'm having trouble, but then I may get pregnant [...] then later [...] / won't use it anymore, because I prefer the injection, I think the injection or a contraceptive is safer than it, because it can blow up and get me pregnant again. (P15)

A study which evaluated female vulnerability to contract STIs found that women are resistant to using the condom, tending to give it little value by claiming it interferes in the pleasure, they are afraid it could burst, or that they feel a burning sensation during intercourse ${ }^{(17)}$.

The influence of the partner in the choice of the contraceptive method is an important factor in the adherence to a correct use of the condom, as the following statements show:

[...] no, we don't forget. Because it's like, he's about to do it with no condom, then, when it's close, he puts it (the condom) [...] sometimes he cums outside right, so, sometimes, he goes without it (the condom)... (P2)

[...] it's because he doesn't like using it [...] I think that between the condom and taking a pill he'd prefer I took a pill, because he doesn't like the condom. (P7)

Gender issues, as well as sociocultural and economic factors, influence in the way people are and behave, leading the relationship of the couple to be guided by models, ideas, and values of what is male and what is female. When men refuse using condoms, they show that the relation is one of inequality, in which women do not find the space to discuss or negotiate the use of the condom, being influenced by affection, by the fear of being seen as a bad wife and losing the partner ${ }^{(17)}$.
[...] the man complained (about the condom), so we weren't using anything, coitus interruptus [...] sometimes that's how l avoided it like with the condom [...], then he went and did it like that, had normal intercourse and when he was about to finish he interrupted it, and that's it [...] yeah, it worked, but $O$ was always bothered. (P10)

In this study, the use of the pill (combined oral hormone contraceptive) seems to not be well accepted or adhered to, since they must remember it and use it every day, which is difficult in the periods of sickle cell crises and recurring hospitalizations, in addition to the fear of the side effects of the pill.

[...] look, I take it, but because they give me, because if I have to get up and take, I won't take it [...] also because the drugs I take make you drowsy, so I may forget taking it [...] It's difficult, we forget anything during the crisis [...] extremely weak, depending on anyone else. (P1)

[...] the pill I forget because we take so much pills right!? I take two, two tablets, hydrea [hydroxyurea] right, one in the morning and one at night. Folic acid, it's so many pills sometimes we forget right? (P5)

Although combined contraception is a risk factor for thromboembolism, in addition to the fact that SCD is a condition that favors thrombosis, there are no evidences in well-designed studies that indicate the two conditions can increase the risk of thrombosis ${ }^{(18)}$. Low-dosage combined contraceptives are classified by the $\mathrm{WHO}^{(6)}$ as category II for SCD, that is, the benefits are found to outweigh the risks.

Regarding to Intrauterine Devices (ID), the participants of this study did not relate it to pain or to a worsening of their framework. However, they showed insecurity and fear concerning the method. For them, the way in which the ID acts and the effects it can bring add to those of SCD are not well clarified, as the statements of these women indicate:

[...] people talk a lot about how it can cause cancer, attract cancer, something like that, so I'm like, you know right. (P6)

[...] I was afraid of the ID, because each person says a different thing, we don't know who to believe in. I'm afraid too, and, I don't know, because, like, I have sickle cell anemia, I know there's a lot of people out there using it, but I'm afraid that something might happen to me. (P8)

The ID has a high contraceptive efficiency and a high rate of continued use. According to the criteria by the $\mathrm{WHO}^{(6)}$, the progesterone ID is classified in category I, while the copper 
ID is classified as category II, since the latter can increase the risk of hemorrhage in women with SCD.

A systematic review about contraception in women with SCD analyzed 9 articles, among which only one evaluated the safety of the ID in 28 women, without specifying the type of ID. Menorrhagia and non-specified infections were described as side effects ${ }^{(18)}$. It should be mentioned that many health workers are not adequately train to place an $I D$, making women insecure in their decision to choose this contraceptive method.

\section{Feelings towards pregnancy}

From the 15 women interviewed in this study, 14 had been through pregnancy, and among these, 8 reported not wanting another pregnancy, to avoid the problems they had to face during the previous ones. For most of them, pregnancy is remembered as a moment of pain and suffering. 7 of them had spontaneous miscarriages in previous pregnancies. Among those whose children lived, all children had the sickle cell trait. The fear of getting pregnant is the main factor for the choice and continuation of a contraceptive method. The desire to be a mother is interconnected with expressions of suffering, as they remember the increase in the number of sickle cell crises and hospitalizations, the fear of dying, of having children with malformations, who cannot survive or who end up suffering with the disease. The moment of pregnancy was a difficult memory to deal with, as the following reports show:

[...] it's not that I don't want to get pregnant, it's because I don't want my child to go through what I have to go through, because it's suffering, it's a lot of suffering for me and my family, who has to help me, because it can attack at any moment. Late in the evening, middle of the night, any time, when it hits they have to take me there fast, because I can't even walk. So I don't want that for my child, I really don't. (P4)

[...] [during pregnancy] / had lots of crises of leg pain, I was always hospitalized, always, always! The doctor here didn't want to discharge me so I could go home [...] every day almost I had to come and receive blood to go through my pregnancy. (P9)

A study which analyzed the perception of women with SCD about pregnancy found negative feelings related to complications in previous pregnancies ${ }^{(19)}$. The feeling of these women is corroborated by literature. In a research about gestational complications of women with SCD, there as a rate of $28.5 \%$ of miscarriages in the first pregnancy. Furthermore, mother-fetus death was related to recurring pain crises, pre- and postpartum infections, congestive heart failure, spontaneous miscarriage, restrict intrauterine growth, pre-eclampsia, fetal malformation, among other complications ${ }^{(3)}$.

Despite the risks found in literature, SCD, by itself, is not a contraindication for pregnancy ${ }^{(6)}$. A thorough prenatal monitoring and the permanent training of professionals to adequately manage the disease are strategies to make pregnancy possible, reducing the risk of mother-fetus morbidity and mortality ${ }^{(3)}$.

Health workers who focus on the gestational risks to the woman with SCD makes them fearful, discouraging women who want to be mothers and contributing to create the mistaken and widely spread notion that women with SCD cannot have children ${ }^{(19)}$. This type of thought is expressed by statements from women who participated in this study, who were attended in other moments:

[...] said that I could die at childbirth, that a child of mine could be born with sickle cell. They said I didn't have a chance. (P4)

[...] they said it was high risk [the pregnancy], explained it wasn't recommended for people with sickle cell anemia.I was even embarrassed when I got pregnant, when I had to tell the doctor. (P9)

\section{Gynecology consultation}

The gynecology consultation was seen as an important space for health monitoring and acquiring knowledge. It was described by most women as the moment in which, in fact, it was possible to know contraceptive methods and have access to contraceptive follow up. The health worker had an essential role in guiding the women in the choice of a contraceptive method. This can be seen in the statements below:

[...] / always heard about the ID, but had never seen one, so when her (the health worker) showed it to be and tell beshewouldn't get pregnant to because she had got one (ID) and that the person can get a period, but that the one she would put in me would make me not have my period. So, it was important to me. It's very important. Because if you have a doubt she's always there to help you and even through the phone she talks to me. (P4)

[...] she explained all of them to me [contraceptive methods] which was better, which I like the most, if I like 
injections, if I don't, if it bothers me, so she laid it out clearly for me and told me to choose. You understand? (P5)

It is necessary to highlight how important the guidance from health professionals is for the process of choosing the methods. The discourse of the women showed that their lack of access to contraceptive information during a large portion of their lives led them to see the difference when they received clear and efficient guidance. As a result, this led to the creation of a bond of trust between them and the health professional, which made it possible for them to have knowledge with regard to the use of methods.

Although health professionals are worried about offering guidance about methods to prevent against pregnancy, the desire of the patient was often not taken into account, hindering the autonomy of the woman over reproductive issues ${ }^{(19)}$.

\section{[...] I'd like to get my period, I told her [health worker] the other time I was here, she asked: why? I told her it's because I miss my period, I want my period [...] She said it's not good for me, the more blood I lose the worse for me [...] l: but doctor, (the period) was only three days. (P4) \\ [...] not that I trust the ID too, but they insisted so, she told me so [the health professional], she talks so much... so I told her, later, who knows, after I get pregnant again, then I'll put it.(P7)}

The technical-scientific knowledge is relevant, since it favors the expansion of care in health. During dialog, one can identify the real needs of the other and make choices that are the most adequate for health care ${ }^{(8)}$. Therefore, attending to women with SCD requires the health worker not only to know the clinical aspects of the disease and the contraceptive methods, as they also must be sensible to issues that involve the patient-worker relation. The health worker has to see"beyond the case"to be able to evaluate the patient as a whole, considering not only the improvement in health, but also the way in which those who seek care are and think ${ }^{(8)}$. Therefore, it is essential to help women with SCD to have autonomy in their process of caring, not to mention their contraceptive issues ${ }^{(20)}$. It also stands out that many health workers can feel unsafe and unprepared to attend women with SCD, which can influence how this group of women choose contraceptives. As a result, it is important for these workers to engage continued education, including educational programs and training, emphasizing the risks of a pregnancy in women with SCD. The same is true for programs that warn these professionals about the unanswered contraceptive demands of this group of women, as well as their need for guidance the offering of effective and safe contraceptive methods.
Nurses are the key to increase the proximity between the services and the women with SCD, since they are the workers who are trained for care, among other skills. The nurses must develop aptitudes for a careful embracing of the woman with SCD, especially in the context of primary care, to strengthen the health team in its search for individualized care and quality in contraceptive assistance ${ }^{(12)}$.

\section{FINAL CONSIDERATIONS}

Reports have shown that the disease goes beyond health conditions, influencing the professional, economic, social, and psychic aspects of these women, and provoking weaknesses in their quality of life and experience with the disease.

It became evident that women with SCD are under the influence of many factors: fear of pregnancy, lack of information on reproductive planning, collateral effects of contraceptive methods, influence of the partner, professional influences, and difficulties to access health services. Considering these potential factors that influence the decision of women in general to use contraception, and especially that of women with SCD, health professionals not only must know and understand these factors, but also know educational actions and strategies to be used at the moment of the contraceptive guidance of each woman, always considering a practice centered around the individual. Factors related to the difficulties to access health services and to continue using contraceptive methods also must be emphasized, to contribute for the implementation of sustainable sexual and reproductive health services. A limitation of this study is that it reflects the perception of a group of women with SCD, which prevents generalization to other groups.

It stands out how important it is to invest in professional training, to make the management of the reproductive planning in SCD better. This study also suggests the development of public policies, financial encouragement, and the structuring of health services, to facilitate the access of women with SCD to contraception.

\section{REFERENCES}

1. Ministério da Saúde (BR). Secretaria de Atenção à Saúde. Portaria conjunta nº 05 , de 19 de fevereiro de 2018. Protocolo clínico e diretrizes terapêuticas da doença falciforme. Brasília: Ministério da Saúde, 2018 [cited 2020 Jan 20]. Available from: http://portalarquivos2.saude.gov.br/images/pdf/2018/fevereiro/22/PortariaConjunta-PCDT-Doenca-Falciforme.fev.2018.pdf

2. Araujo OMR, Ivo ML, Ferreira Júnior MA, Pontes ERJC, Bispo IMGP, Oliveira ECL. Survival and mortality among users and non-users of hydroxyurea with sickle cell disease. Rev Latino-Am Enfermagem. 2015;23(1):67-73. doi: https://doi. org/10.1590/0104-1169.3385.2526 
3. Silva FAC, Ferreira ALCG, Hazin-Costa MF, Dias MLG, Araújo AS, Souza Al. Adverse clinical and obstetric outcomes among pregnant women with different sickle cell disease genotypes. Int J Gynecol Obstet. 2018;143(1):89-93. doi: https:// doi.org/10.1002/ijgo.12626

4. Laguardia J. No fio da navalha: anemia fal ciforme, raça e as implicações no cuidado à saúde. Rev Estud Fem. 2006;14(1):243-62. doi: https://doi.org/10.1590/ S0104-026X2006000100013

5. Presidência da República (BR). Lei no 9.263, de 12 de janeiro de 1996. Regula 0 § 70 do art. 226 da Constituição Federal, que trata do planejamento familiar, estabelece penalidades e dá outras providências. Brasília, DF; 1996 [cited 2020 Feb 03]. Available from: http://www.planalto.gov.br/ccivil_03/leis/19263.htm

6. World Health Organization (CH). Medical elegibility criteria for contraceptive use. 5th ed. Geneva: WHO; 2015 [cited 2020 Jan 02]. Available from: https:// apps.who.int/iris/bitstream/handle/10665/181468/9789241549158_eng.pdf

7. Rizo AA, Bhor M, Lin X, McCausland KL, White MK, Paulose J, et al. The relationship between frequency and severity of vaso-occlusive crises and health-related quality of life and work productivity in adults with sickle cell disease. Qual Life Res. 2020;29(6):1533-47. doi: https://doi.org/10.1007/s11136-019-02412-5

8. Gadamer HG. 0 caráter oculto da saúde. Petrópolis: Vozes; 2006.

9. Nascimento LCN, Souza TV, Oliveira ICS, Moraes JRMM, Aguiar RCB, Silva LF. Theoretical saturation in qualitative research: an experience report in interview with schoolchildren. Rev Bras Enferm. 2018;71(1):228-33. doi: https://doi. org/10.1590/0034-7167-2016-0616

10. Bardin L. Análise de conteúdo. São Paulo: Edições 70; 2016.

11. Ministério da Saúde (BR). Doença falciforme: condutas básicas para o tratamento. Brasília, DF: Ministério da Saúde; 2013 [cited 2020 Jan 02]. Available from: http://bvsms.saude.gov.br/bvs/publicacoes/doenca_falciforme_condutas_ basicas_tratamento.pdf
12. Moura LNB, Gomes KRO. Planejamento familiar: uso dos serviços de saúde por jovens com experiência de gravidez. Ciênc Saúde Coletiva. 2014;19(3):853-63. doi: https://doi.org/10.1590/1413-81232014193.10902013

13. Shamian J. 0 papel da enfermagem na atenção à saúde [editorial]. Rev Bras Enferm. 2014;67(6):869-70. doi: https://doi.org/10.1590/0034-7167.2014670601

14. Bahamondes L. A escolha do método contraceptivo. Rev Bras Ginecol Obstet. 2006;28(5):267-70. doi: https://doi.org/10.1590/S0100-72032006000500001

15. Carvalho NS, Braga JP, Barbieri M, Torloni MR, Figueiredo MSW, Guazzelli CAF. Contraceptive practices in women with sickle-cell disease. J Obstet Gynaecol. 2017;37(1):74-77. doi: https://doi.org/10.1080/01443615.2016.1225023

16. Xavier ASG, Medeiros LD, Ferreira, SL. Use of contraceptive methods by women with sickle cell anemia. Cienc Cuid Saude. 2014 [cited 2020 Jan 02];13(1):27-34. Available from: http://periodicos.uem.br/ojs/index.php/CiencCuidSaude/article/ view/19459/pdf_139

17. Silva CM, Vargens OMC. Women's perception about female vulnerability to STD and HIV. Rev Esc Enferm USP. 2009 [cited 2020 Jan 02];43(2):401-6. Available from: https://doi.org/10.1590/50080-62342009000200020

18. Haddad LB, Curtis KM, Legardy-Williams JK, Cwiak C, Jamieson DJ. Contraception for individuals with sickle cell disease: a systematic review of the literature. Contraception. 2012;85(6):527-37. doi: https://doi.org/10.1016/j. contraception.2011.10.008

19. Xavier ASG, Ferreira SL, Carvalho ESS, Araújo EM, Cordeiro RC. Perception of women suffering from sickle cell anemia regarding pregnancy: an exploratory study. Online Braz J Nurs. 2013;12(4):834-43. doi: https://doi. org/10.5935/1676-4285.20134289

20. Silvia RCC, Ferreira SL, Santos ACC. The illness of women and men with sickle cell disease: a Grounded Theory study. Rev Latino-Am Enfermagem. 2015;23(6):111320. doi: https://doi.org/10.1590/0104-1169.0594.2656 


\section{- Acknowledgement:}

To FACEPE - Fundação de Amparo à Ciência e Tecnologia de Pernambuco (the Foundation for the Support to Science and Technology in Pernambuco), for the PhD scholarship (Process: IBPG-0860-4.01/16), given to Evelyne Nascimento Pedrosa.

\section{- Authorship contribution:}

Conceptualization: Maria Suely Medeiros Corrêa, Evelyne Nascimento Pedrosa and Ariani Impieri Souza. Data curation: Maria Suely Medeiros Corrêa, Caroline Eloisa da Silva Sousa and Rayane Alves da Silva. Formal analysis: Maria Suely Medeiros Corrêa, Evelyne Nascimento Pedrosa, Caroline Eloisa da Silva Sousa and Rayane Alves da Silva. Investigation: Evelyne Nascimento Pedrosa, Caroline Eloisa da Silva Sousa and Rayane Alves da Silva. Methodology: Maria Suely Medeiros Corrêa, Evelyne Nascimento Pedrosa, Ana Laura Carneiro Gomes Ferreira and Ariani Impieri Souza.

Project administration: Maria Suely Medeiros Corrêa and Ariani Impieri Souza.

Supervision: Evelyne Nascimento Pedrosa, Ana Laura Carneiro Gomes Ferreira and Ariani Impieri Souza. Writing - original draft, revision and editing: Evelyne Nascimento Pedrosa, Maria Suely Medeiros Corrêa, Ana Laura Carneiro Gomes Ferreira, Caroline Eloisa da Silva Sousa, Rayane Alves da Silva and Ariani Impieri Souza.

\section{- Corresponding author:}

Ariani Impieri Souza

Email: ariani@imip.org.br 